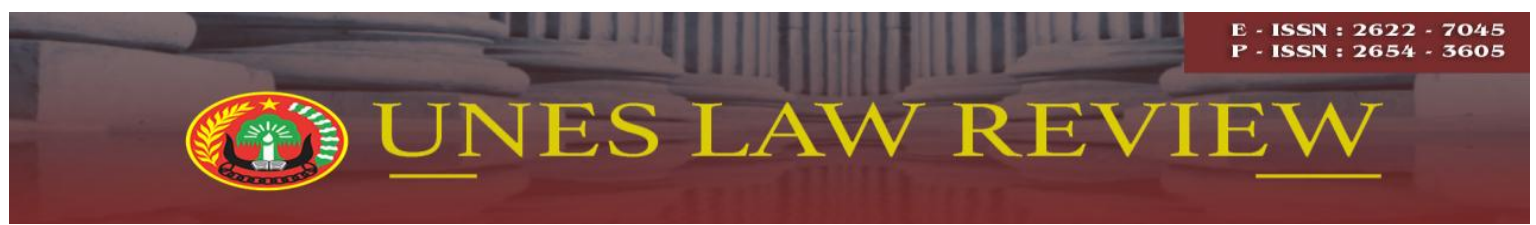

Email: uneslawreview@gmail.com

Online: http://review-unes.com/index.php/law

Volume 2, Issue 3, Maret 2020

\title{
IMPLEMENTASI FUNGSI STATISTIK KRIMINAL DALAM PENANGGULANGAN TINDAK PIDANA DI KOTA PADANG
}

\author{
Edryan Wiguna \\ Kepolisian Resor Kota Padang, Padang, Indonesia \\ E-mail : edryan85@gmail.com
}

\begin{abstract}
The compilation of criminal statistics must be used for decision making in dealing with crime. This research is a legal research with analytical descriptive specifications. The approach used is the Normative Juridical approach supported by empirical juridical. The urgency of compiling criminal statistics by the Padang Satreskrim Polres is to provide an overview / data about existing crime in the community, such as the number, frequency and distribution of the perpetrators and their crimes. The technique of compiling criminal statistics by Padang Police is to present the first data. The handling of criminal offenses by using criminal statistics is done by the Satreskrim Padang Police by applying two methods, namely a method to reduce repetition of crime and a method to prevent the first crime, which is a way aimed at preventing the occurrence of the first crime (the first crime) to be committed by someone and this method is also known as prevention (preventive) method.
\end{abstract}

Kata Kunci: Statistik Kriminal, Penanggulangan Tindak Pidana, Metode

\section{PENDAHULUAN}

Statistik kriminal dibagi kedalam dua bagian, yaitu yang pertama statistik yang disusun secara berkala dan yang kedua statistik yang disusun secara bebas. Pada umumnya untuk jenis statistik pertama dikenal dengan statistik kriminal resmi dan untuk jenis kedua dikenal dengan statistik kriminal yang tidak resmi. Statistik resmi dibuat berdasarkan pelangaran hukum dan pelangaran undang-undang sedangkan statistik kriminal yang tidak resmi diperoleh secara bebas dari catatan mengontrol kejahatan, baik berasal dari pencatatan pribadi, agen-agen investigasi, hasil penelitian dan observasi (Arif Rohman: 2016:128).

Statistik kriminal dibuat oleh kepolisian dalam hal ini statistik kriminal dibuat dalam bentuk data-data yang memberikan gambaran mengenai perkembangan kejahatan yang ada di dalam masyarakat seperti lajunya, kejahatan yang menonjol dan penyelesaianya (Anthon F.Susanto, 2011:34). Melihat dari data statistik kriminal dapat diketahui bahwa angka kejahatan (kriminalitas) yang terjadi dari tahun ketahun naik turun namun cenderung 
mengalami peningkatan. Penyusunan statistik kriminal oleh Kepolisian berdasar Undang undang Nomor 2 Tahun 2002 tentang Kepolisian Republik IndonesiaPasal 15 ayat (1) huruf j.

Mengacu pada data kriminalitas yang ada di wilayah hukum Polres Padang yang dikeluarkan oleh Sat Reskrim Polres Padang dalam lima tahun terakhir yakni dari tahun 2015 sampai 2019 menunjukan frekuensi yang fluktuasi naik turun dimana pada tahun 2015 terdapat 1723 laporan polisi, pada tahun 2016 mengalami penurunan 1411 kasus, pada tahun 2017 mengalami sedikit kenaikan yakni 1831 laporan polisi, pada tahun 2018 juga mengalami penurunan dengan 1705 laporan polisi sementara tahun 2019 sampai bulan Mei sejumlah 318 laporan polisi.

Data kriminalitas ini hanya mencakup seluruh peristiwa atau kejadian kriminalitas yang dilapor-kan oleh masyarakat, atau aksi kriminalitas yang pelakunya tertang-kap tangan oleh kepolisian. Meng-ingat masih tingginya keengganan masyarakat untuk melapor, diduga data yang dihasilkan cenderung "under-estimate". Artinya, kejadian kriminalitas yang sesungguhnya diduga lebih besar dari yang dilaporkan. Dengan kata lain, angka gelap (dark number) kejahatan masih relatif besar.

Berdasarkan latar belakang pemikiran di atas, maka permasalah-an adalah urgensi dan teknik penyusunan statistik criminal, serta implementasi fungsi statistik kriminal oleh Satreskrim Polresta Padang dalam upaya penang-gulangan tindak pidana di kota Padang.

\section{METODE PENELITIAN}

Spesifikasi penelitian adalah deskriptif analitis, dengan metode pendekatan yuridis normative didukung oleh yuridis empiris. Jenis data yang digunakan adalah data sekunder. Data sekunder diperoleh dari studi dokumen dan studi kepustakaan. Data yang diperoleh kemudian dianalisa secara kualitatif .

\section{HASIL PENELITIAN DAN PEMBAHASAN}

\section{Urgensi dan Teknik Penyusun-an Statistik Kriminal Oleh Satreskrim Polresta Padang}

Metode statistik kriminal dipakai untuk melihat realitas kejahatan yang terjadi pada masyarakat, ada anggapan atau persepsi bahwa statistik kriminal merupakan pencerminan kejahatan yang ada dalam masyarakat, sehingga menimbulkan pandangan bahwa penjahat 
diartikan sama dengan orang-orang yang telah dijatuhi hukuman resmi. Sebuah statistik kriminal yang diharapkan dapat menjadi pedoman dalam melihat tingkat realita kejahatan, pihak kepolisian dalam membuat statistik kriminal kemudian memperhatikan dan mencermati adanya trend kejahatan yang fluktuasi naik-turun.

Hal itu sangat diperlukan untuk mengetahui bentuk-bentuk kejahatan apa yang perlu mendapat perhatian dan keseriusan dalam melakukan usaha preventif atau persuasif, paling tidak untuk dapat menekan lajunya kenaikan angka kejahatan tersebut. Pengunaan metode statistik kriminal dalam kajian kriminologi juga merupakan masalah yang penting dalam hukum pidana, karena hal ini berkaitan dengan kebijakan hukum pidana dalam meminimalisir dan mengatasi kejahatan di masyarakat.

Tujuan dibuatnya statistik kriminal oleh Satreskrim Polresta Padang adalah untuk memberikan gambaran/data tentang krimina-litas yang ada pada masyarakat, seperti jumlahnya, frekuensi serta penyebaran pelaku dan kejahatan-nya. Berdasarkan data tersebut kemudian oleh Polresta Padang bersama pemerintah dipakai untuk menyusun kebijakan penang-gulangan kejahatan, sebab dengan data kejahatan tersebut dapat diukur naik turunnya kejahatan pada suatu periode tertentu disuatu daerah. Disamping untuk tujuan praktis, khususunya bagi tujuan penegak hukum dan pemerintah, statistik kriminal juga dipakai oleh para ilmuwan, khususnya kriminologi, untuk menjelaskan fenomena kejahatan atau menyusun teori.

Fungsi utama dari statitistik kriminal ialah untuk mengetahui jumlah kejahatan yang terjadi agar dapat dilakukan penanggulangannya dengan tepat seperti melakukan upaya pre-emtif yaitu penanaman norma-norma sejak dini kepada masyarakat, upaya preventif seperti melakukan patroli dan pemasangan spanduk-spanduk peringatan, terakhir yaitu upaya represif berupa tindakan tegas dalam penanganan masalah kejahatan untuk mengurangi angka kejahatan tiap tahunnya.

Statistik kriminal mem-punyai arti yang sangat penting, bukan saja sebagai metode dan data mengenai kejahatan, akan tetapi peranan terkait membentuk gambaran orang mengenai realitas kejahatan atau sebagai konstruksi sosial tentang realitas maupun praktik kejahatan. Di lihat dari sejarahnya Adolphe Quetelet (1776-1874) adalah ahli statistik dan guru besar atronomi asal belgia yang telah berhasil menjadikan statistik suatu metode ilmu pengetahuan serta menciptakan dasar-dasar statistik praktis. Dialah yang menggunakan 
data statistik kriminal di Perancis, dimana untuk pertama kali membuktikan bahwa kejahatan, seperti halnya kejadian-kejadian sosial lainnya seperti kelahiran dan kematian dan juga kejahatan merupakan lebih dari sekedar kejadian yang bersifat perseorangan tetapi fenomena yang bersifat massal, sehingga statistik kriminal menjadi metode dalam mempelajari kejahatan yang bersifat massal tersebut, yaitu dalam menentukan keteraturan, kecen-derungan. atau bahkan hukum-hukum sosial. Pengamatannya yang sangat terkenal dari Quetelet adalah bahwa jumlah dan jenis-jenis kejahatan di negara tertentu setiap tahun cenderung sama dan juga cara melakukannya sama(Aloysius Wisnubroto, 1999:79).

Bentuk statistik kriminal di wilayah hukum Polresta Padang adalah dengan membuat suatu data statistik kriminal dalam bentuk sistim manual dengan mencatat laporan kejahatan yang terjadi di masyarakat. Dalam pencatatan laporan kejahatan yang terkumpul maka pihak petugas dari Sat Reskrim Polresta Padang membuat sebuah tabel dengan memuat 44 jenis tindak pidana umum dan 9 jenis tindak pidana khusus. Jumlah kejahatan yang ada tercatat oleh petugas kepolisian selanjutnya petugas menyesuaikan data-data dengan angka-angka kejahatan yang dijumlahkan setiap bulannya berdasarkan laporkan oleh masyarakat serta dari hasil operasi yang ditemukan oleh pihak kepolisian. Statistik kriminal yang dibuat oleh Sat Reskrim Polresta Padang memuat jumlah laporan dari masyarakat dan penyelesaian dari laporan tersebut.

Selain memuat laporan dari masyarakat statistik kriminal yang ada di wilayah hukum Polres Padang juga memuat mengenai kejahatan yang ditemukan oleh pihak kepolisian dalam berbagai operasi yang dilakukan di dalam masyarakat. Pembuatan statistik kriminal petugas kepolisian Polresta Padang membuat data statistik kriminal dengan menyusun data-data yang terkumpul pada setiap bulan. Urgensi pembuatan statistik pada setiap bulan bertujuan agar setiap angka kejahatan yang cenderung tinggi terjadi setiap bulan, dapat menjadi perhatian dan dapat ditanggulangi oleh pihak kepolisian yang berada di wilayah hukum Polresta Padang.

\section{Implementasi Fungsi Statistik Kriminal Oleh Satreskrim Polresta Padang Dalam Upaya Penanggulangan Tindak Pidana Di Kota Padang}

Upaya penanggulangan kejahatan telah dan terus dilakukan oleh pemerintah maupun masyarakat. Berbagai program dan kegiatan telah dilakukan sambil terus menerus mencari cara paling tepat dan efektif untuk mengatasi masalah tersebut. Upaya atau 
kebijakan untuk melakukan pencegahan dan penang-gulangan kejahatan termasuk bidang kebijakan kriminal. Kebijakan kriminal ini pun tidak terlepas dari kebijakan yang lebih luas, yaitu kebijakan sosial yang terdiri dari kebijakan atau upaya-upaya untuk kesejahteraan sosial dan kebijakan/ upaya-upaya untuk perlindungan masyarakat (Barda Nawawi Arief, 2001:77).

Langkah-langkah preventif sebagai upaya penanggulangan terhadap tindak pidana menurut Baharuddin Lopa (2001:16-17) meliputi: pertama, Peningkatan kesejahteraan rakyat untuk mengurangi pengangguran, yang dengan sendirinya akan mengurangi kejahatan; kedua, Memperbaiki sistem administrasi dan pengawasan untuk mencegah terjadi-nya penyimpangan-penyimpangan; ketiga, Peningkatan penyuluhan hukum untuk memeratakan kesadaran, keempat, Menambah personil kepolisian dan personil penegak hukum lainnya untuk lebih meningkatkan tindakan represif maupun preventif; kelima, Meningkatkan ketangguhan moral serta profesionalisme bagi para pelaksana penegak hukum. Solusi preventif adalah berupa cara-cara yang cenderung mencegah kejahatan. Solusi supresif adalah cara-cara yang cenderung menghentikan kejahatan sudah mulai, kejahatan sedang berlangsung tetapi belum sepenuhnya sehingga kejahatan dapat dicegah. Solusi yang memuaskan terdiri dari pemulihan atau pemberian ganti kerugian bagi mereka yang menderita akibat kejahatan. Sedangkan solusi pidana atau hukuman juga berguna, sebab setelah kejahatan dihentikan pihak yang dirugikan sudah mendapat ganti rugi, kejahatan serupa masih perlu dicegah entah dipihak pelaku yang sama atau pelaku lainnya. Menghilangkan kecenderungan untuk mengulangi tindakan adalah suatu reformasi. Solusi yang berlangsung karena rasa takut disebut hukuman.

Penanggulangan kejahatan merupakan suatu kebijakan yang dapat diambil oleh pihak kepolisian yang berada diwilayah hukum Polresta Padang. Kebijakan penanggulangan kejahatan dilakukan agar tercapainya rasa aman dan damai di tengahtengah masyarakat dari para pelaku tindak pidana. Penanggulangan tindak pidana dengan berdasarkan statistik kriminal dilakukan Satreskrim Polresta Padang dengan menerapkan dua buah metode yaitu metode untuk mengurangi pengulangan dari kejahatan. Merupakan suatu cara yang ditujukan kepada pengurangan jumlah residivis (pengulangan kejahatan) dengan suatu pembinaan yang dilakukan secara konseptual. 
Metode untuk mencegah the first crime. Merupakan satu cara yang ditujukan untuk mencegah terjadinya kejahatan yang pertama kali (the first crime) yang akan dilakukan oleh seseorang dan metode ini juga dikenal sebagai metode prevention (preventif).

Polresta Padang telah melakukan berbagai kegiatan untuk menekan tingginya angka kejahatan yang terjadi dengan melihat dan mengunakan statistik kriminal. Dengan mengunakan statistik kriminal tersebut maka terlihat pada angka kejahatan yang paling tinggi di wilayah hukum Polresta Padang adalah tindak pidana Penipuan dan pencurian kendaraan bermotor. Maka kebijakan yang dapat diambil oleh pemerintah untuk menangulangi tingginya angka kriminalitas tersebut ada 2 yakni secara preventif dan secara represif.

Upaya preventif yaitu usaha-usaha yang dilakukan oleh pihak kepolisian yang sifatnya mencegah serta memperkecil ruang gerak dari pelaku kejahatan. Upaya preventif ini juga bertujuan untuk menghilangkan kesempatan para pelaku untuk melakukan kejahatan.

Penanggulangan kejahatan secara preventif dilakukan oleh anggota Satuan Reserse Kriminal yang berada di wilayah hukum Polresta Padang. Kebijakan secara prepentif dilakukan dengan cara pengawasan terpadu secara patroli-patroli di tengah-tengah masyarakat. Patroli-patroli dilakukan didaerah-daerah yang rawan menjadi tempat pelaku kejahatan beraksi.

Kepolisian juga memberikan himbauan kepada masyarakat untuk selalu berhati-hati kepada masyarakat agar terhindar dari tindak pidana. Himbauan ini dilakukan oleh pihak kepolisian baik secara lisan maupun tulisan. Dengan cara lisan pihak kepolisian memberikan himbauan dengan patroli-patroli dengan mobil dinas polisi serta mengunakan alat pengeras suara untuk menghimbau masyarakat agar berhati-hati serta selalu waspada .

Lokasi yang dipilih oleh pihak kepolisian yang berada di wilayah hukum Polresta Padang adalah tempat tempat yang rawan terjadi tindak pidana. Untuk secara tulisan penanggulangan kejahatan yang dilakukan oleh pihak kepolisian di wilayah hukum Polresta Padang adalah dengan cara memberikan himbauan secara tetulis. Himbauan secara tertulis yang dimaksud adalah dengan membuat spanduk-spanduk oleh pihak kepolisian agar masyarakat berhati-hati dan menghindari hal-hal yang dapat memancing pelaku tindak pidana untuk melakukan aksinya. Himbauan dalam bentuk spanduk di tempat-tempat 
keramaian seperti di tempat parkir, di daerah pasar, di daerah-daerah yang rawan terjadinya tindak pidana.

Pihak kepolisian yang berada di wilayah hukum Polresta Padang melihat dan serta mengamati statistik kriminal yang ada serta mengambil suatu kesimpulan. Maka kepolisian merencanakan dan melakukan sebuah penanggulangan secara preventif berdasarkan trend kejahat-an yang tercatat.

\section{PENUTUP}

Urgensi penyusunan statistik kriminal oleh Satreskrim Polresta Padang adalah untuk memberikan gambaran/data tentang kriminalitas yang ada pada masyarakat, seperti jumlahnya, frekuensi serta penyebaran pelaku dan kejahatannya. Berdasarkan data tersebut kemudian oleh Polresta Padang bersama pemerintah menggunakan untuk menyusun kebijakan penang-gulangan kejahatan. Teknik penyusunan statistik kriminal Oleh Polresta Padang adalah menyajikan data pertama yaitu data tentang banyaknya tindak pidana yang dilaporkan dan diselesaikan pada tingkat penyidikan dalam bentuk Tabel.

Penanggulangan tindak pidana dengan menggunakan statistik kriminal dilakukan Satreskrim Polresta Padang dengan menerapkan dua metode yaitu Metode untuk mengurangi pengulangan dari kejahatan yaitu dengan cara yang ditujukan kepada pengurangan jumlah residivis (pengulangan kejahatan) dan Metode untuk mencegah the first crime yaitu satu cara yang ditujukan untuk mencegah terjadinya kejahatan yang pertama kali (the first crime) yang akan dilakukan oleh seseorang.

\section{DAFTAR PUSTAKA}

\section{Buku Taks:}

Anthon F.Susanto, Statistik Kriminal Sebagai Kontruksi Sosial, Genta Publishing, Yogyakarta, 2011.

Aloysius Wisnubroto, Kebijakan Hukum Pidana dalam Penanggulangan Penyalahgunaan Komputer, Universitas Atma Jaya Yogyakarta, Yogyakarta, 1999

Barda Nawawi Arief, Masalah Penegakan Hukum dan Kebijakan penanggulangan Kejahatan, Bandung, 2001

Baharuddin Lopa, Kejahatan Korupsi dan Penegakan Hukum, Penerbit Buku Kompas, Jakarta, 2001 


\section{Undang-Undang:}

Undang-Undang Nomor 2 Tahun 2002 tentang Kepolisian Republik Indonesia

Web, Karya Ilmiah \& Journal:

Arif Rohman, "Upaya Menekan Angka Kriminalitas Dalam Meretas Kejahatan Yang Terjadi Pada Masyarakat”, Vol.XXI No2, Tahun 2016.

Nasional Tempo, Tingkat Kriminalitas di Indonesia, https://NasionalTempo 